\title{
THE ALEXANDRA OUTRAGE, 13th FEBRUARY 1942
}

\author{
Colonel W. J. IRWIN, L.R.C.P.I. \& L.M., L.R.C.S.I. \& L.M., Late R.A.M.C.
}

IT is now 30 years since the fall of Singapore and we mark this occasion by publication of the following account of what happened at the British Military Hospital. We are also indebted to the Author for a roll of the staff of the hospital preserved in a Chinese laundry book, which together with the original book and related correspondence is now in the Historical Library, Millbank. EDIToR.

"There is such a thing as legitimate warfare; war has its laws; there are things which may be fairly done and things which may not be done."

John Henry, Cardinal Newman

“Apologia pro Vita Sua" 1864

In war, and more particularly in battle, death and injury become commonplace and one of man's most primitive and strongest impulses-that of aggression, becomes uppermost. One of his other vital urges, that of survival, also comes to the fore and not often have these features been shown in more unlikely surroundings than as on the day when the Japanese captured the British Military Hospital (B.M.H.) in Singapore on 13th February 1942. Seldom has the cliche that truth is stranger than fiction been more valid than when applied to what happened on the day of the 13th which has become known as Black Friday. Traditionally, a hospital is a place of peace and healing. On 13th February the B.M.H. was a place of carnage and slaughter.

The first military hospital was built on the island of Blakang Mati just off Singapore. Its short life from 1909 to 1912 was finished when a new hospital was opened in Tanglin.

By 1938 the need for a larger hospital became evident and work began on the present hospital in Alexandra which is bounded by the railway line on one side and primary jungle on the other. Ayer Rajah Road existed only as a track and the present row of shops and attap shanties only came into existence later as a result of the trade offered them by the hospital. At the same time, quarters were built across the railway line in Alexandra Park. So was the Nursing Officers' Mess as it exists today. The new hospital was called Military Hospital Alexandra and consisted of 600 beds. It catered for troops and officers. Previously officers and families had to attend the Singapore General Hospital. The first Commanding Officer was Colonel Craven. It is interesting to note that Lieutenant-Colonel G. Atkins, the Officer Commanding Designate and Commanding B.M.H. Tanglin, noted the juxtaposition of the hospital to oil storage tanks in Ayer Rajah Road and protested against the proximity but it was too late to do anything about this. Lieutenant-Colonel Atkins became ill and was evacuated before the new hospital was completed.

The R.A.M.C. Officers' Mess was built in the grounds but no trace of it remains today. The following officers were on the staff of the hospital when it opened and remained so until its capture by the Japanese. Colonel J. W. Craven, Major E. Smyth, Officer Commanding Surgical Division assisted by Captain T. B. Smiley, Major T. Rogan, Medical Specialist, Major L. Webster, Captain Young, G.D.M.O., Major J. Bull, Captain E. Cruickshank, Captain J. Allerdyce, Lieutenant W. F. Weston. The present B.M.H. is a stately building built on the gracious lines of old Colonial archi- 


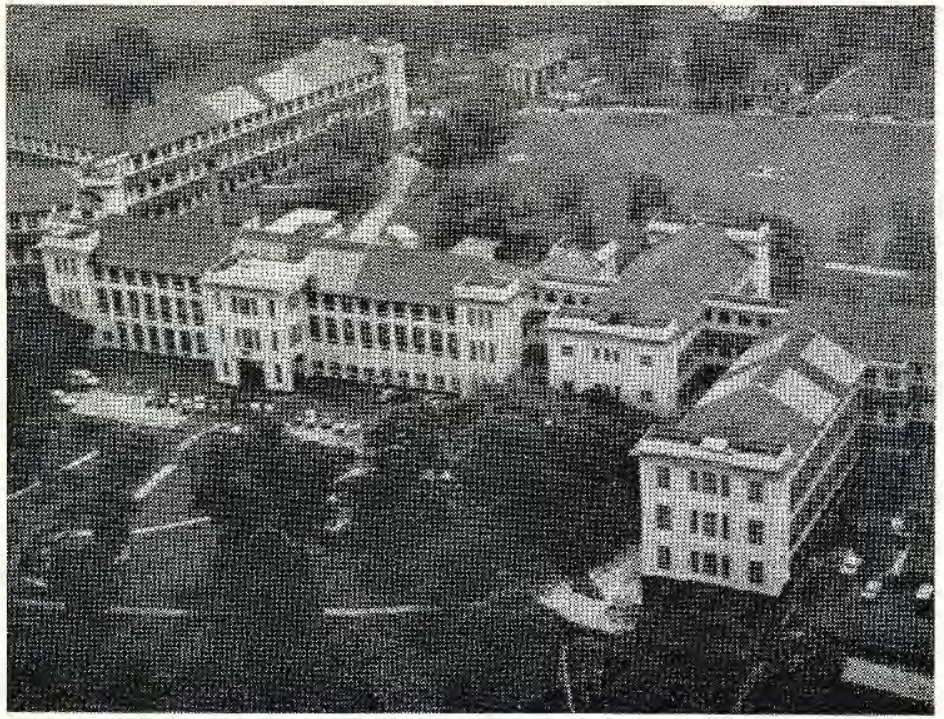

British Military Hospital, Singapore, formerly Military Hospital Alexandra.

tecture. It was described to me by one if its Commanding Officers as "One of the nicest hospitals I've ever worked in ". Any institutional look is taken away by its being surrounded by a profusion of flowering shrubs and trees.

On Monday 8th December, 1941 the Malayan Campaign began when the Japanese invaded the peninsula near Kota Bahru. So much has been written about the military disasters of the Campaign, with their unanswered questions by amateur and professional historians and journalists, that here I want simply to concentrate on the effect of the Japanese invasion on the B.M.H. Through the Campaign the hospital functioned as a very busy base hospital. Perhaps it's busiest period was when it had to deal with the injured men from the doomed "Prince of Wales" and "Repulse" battleships, many of them suffering from burns and a peculiar fracture of their foot bones-largely of the os calcis, said to have been caused by jumping from one deck to another. On the night of 8th February, the Japanese landed on the northern side of Singapore, and by the afternoon of Thursday, the 12th February, they made towards Alexandra Park and the back of the hospital, having captured Kent Ridge. The oil storage tanks were set on fire and the hospital was shrouded in thick smoke and oil fumes. The normal sodden humidity of Singapore's climate was immensely increased by the heat from the burning oil. This could be felt inside the hospital and oil was seen running down the railway line and Ayer Rajah Road.

The advance of the enemy was no great surprise to those in the hospital as on the 11 h February orders had been received that the hospital was not to be evacuated as the Japanese were not observing the Geneva Convention the Principal Matron, V. M. E. Jones, interviewed all the nursing sisters and gave them the option of boarding a ship for home on the 11th February. The majority agreed to stay, but as the position became increasingly hopeless all the sisters were ordered to leave on the 13th February and were taken down to Singapore Cricket Club in ambulances. Many of them boarded the coaster "Kuala", only to be spotted and bombed and some were interned in 
Sumatra for the war. Others had remarkable escapes, none more fantastic than that of our retired Director of Army Nursing Services, Dame Margot Turner, D.B.E., R.R.C.

Apart, therefore, from the rather inadequate accounts already written about what happened when the Japanese took over the B.M.H. on the 13th February, we are left with details given by men who were actively engaged in the incident, viz: Private Saye, R.A.M.C., Captain T. B. Smiley and Sergeant H. M. Gordon, Corporal J. Torbit, dispenser and Captain Bewick, a patient. It is part of the human condition that individual accounts and happenings, especially those involving death and disaster, will vary. Some men will remember one thing and some another; an incident that is highlighted for one man will be blotted out from another's brain, and when an individual's own safety is in danger as it is in battle, then the eye-witness accounts must be increasingly at variance. However, in the above men's accounts, there is a basic similarity in their style of relating the terrible events, although they speak of different things. It is this undramatic, almost matter-of-fact, style of writing that makes what they have to say all the more striking and demonstrates their own bravery and that of their colleagues.

In spite of the noise of the shelling which had by now commenced and the choking fumes from the burning oil tanks, the top floor of the hospital was evacuated and every bit of available space on the ground floor of the hospital was packed with patients. Water and electricity had been cut off for some days before, but fortunately there was some water available from stocks kept in baths and other containers. The water was rationed out with strict economy.

Japanese troops were seen for the first time at about 1140 hours attacking from the rear of the hospital. They were held up for a time by the Loyal Regiment and the 22nd Punjabi Regiment but to no avail, and eventually the Punjabi Regiment had to withdraw back through the hospital and to cover their retreat, established machine gun posts on the first and second floors of the hospital. Private Saye describes the hail of mortars increasing as the Japanese approached. There were bodies everywhere. The air was full of smoke and the groans and cries of the sick pleading for attention and for water, trying to make themselves heard above the noise. In a burst of descriptiveness, which no writer could invent, he adds "The soles of my shoes were thick with blood". The incredible thing is that morale amongst the hospital staff remained high and there appears to have been no panic amongst the band of men tending the sick and the wounded. Lieutenant Weston, wearing a Red Cross Brassard and carrying a white flag, proceeded from reception to the rear of the hospital to signify its surrender. The Japanese either did not see the flag or, as is more likely, took no notice of the young officer's pleas for mercy and the shouts of his comrades of "Hospital ". They bayoneted Lieutenant Weston to death and then entered the hospital.

It appears that the Japanese were under no senior command and would seem to have been infected by a sort of mass desire to kill. Certainly they entered the hospital corridors and added to the horror of the scene by bayoneting patients and staff indiscriminately.

Captain T. Smiley now takes up the story using the same economy of phrase and underplaying his courage that makes the account so grippingly authentic. A man with a bleeding leg wound was brought to theatre and in spite of what must have been the obvious danger to all, operation on the wounded man commenced. The patient, Corporal Robert Veitch of the Armoured Car Battalion, was anaesthetised by Captain Allerdyce 
and the surgeon, Captain Smiley was assisted by three orderlies. In spite of the fact that he knew that the Japanese were outside, he continued to operate in what surely must have been the most difficult and dangerous conditions in which surgery has ever been performed. until the operation was completed, when a bullet was fired into the theatre by Japanese soldiers who had appeared at a window. It struck an orderly in the arm. A Japanese soldier bounded into the theatre and motioned those present to go outside, first killing the still anaesthetised patient whose passing must have been less painful than that of Captain Allerdyce, who was then bayoneted to death.

The survivors were lined up against a wall outside and a Japanese soldier lunged at Captain Smiley, but fortunately the bayonet struck a silver cigarette box: (still in his possession) another thrust by the soldier at Captain Smiley's groin, or as he says himself with a surgeon's precise regard for anatomy "It went into my iliac fossa"; a third jab with the bayonet was intercepted by Captain Smiley's hand and the weapon caught his thumb, or as he says again with a nice regard for anatomy, "my thenar eminence was cut open ". With admirable presence of mind he then feigned death, while shouting to Corporal Sutton to do the same. When the Japanese moved away, Smiley and Sutton were the only two men left alive. The Japanese hunger for blood was still not assuaged and they ran amok through the hospital, which by now resembled a battlefield with the bodies of the dead and the ill strewn everywhere and those of the hospital staff, who tried to protect the patients, killed or injured according to their luck. The suffocating heat was now increased by the sickly smell of human blood.

At last, the Japanese must have decided that they had killed and injured enough because they ordered those of the patients and staff who were left, about 400 in all, to be tied together, one length of cord often being used for a group of four to five men and they were then marched to a destination about which there would seem to have been some argument. Some accounts say it was in the coolie lines or the old servants' quarters, but the general concensus of opinion would appear to agree that the men were sent to a bungalow in Alexandra Park. Although their destination had some mystery attached to it, what befell the unfortunate men is quite definite-all but one were killed.

At first they were incarcerated into rooms, 50 to 70 men to a room, the sizes of which varied from $9^{\prime} \times 9^{\prime}$ to $10^{\prime} \times 12^{\prime}$. Bodies, which were now covered with dirt, sweat and in many cases blood, were crammed against each other and mostly it was impossible to raise a hand over the head. The stench of exhausted and ill bodies was increased by the fact that men were forced to urinate and defecate against each other. The physical effects of not knowing what was to befall them must have been worse. Especially as from what they had seen at the hospital, it must have seemed to them unlikely that they would be shown mercy.

Their fears were fully justified because many men died from thirst and general exhaustion, and the Japanese took absolutely no notice. Indeed, a survivor reported that when dawn came, some Japanese soldiers could be seen devouring tinned fruit. Water was promised to the dying and the injured, but none came. The imprisoned men's discomfort was now increased by shells bursting around the building. One struck the roof and injured a few of the men inside. When this happened about 8 men tried to escape, but only one seems to have been successful. He was an officer, name unknown, but remembered by Captain Smiley as a rugby playing infantry officer. He stumbled out of the building and under the hail of shell fire and the pluming smoke of the burning oil, he managed to make his way back to the hospital covered all over in oil. 
There is little doubt that towards dawn the imprisoned men were taken out in twos and threes, having been kept without food or water for 24 hours, and then shot. This mass killing was apparently ordered by a very junior Japanese officer who, when more senior Japanese officers appeared on the scene some half an hour later, was shot with some others for his part in the outrage. Now, with the arrival of more senior Japanese officers, an order was given that all movement must cease at the hospital, although it must be recorded that Major Webster and Captain Smiley bravely defied this order and continued to tend the patients.

On the following day, 15th February, the Japanese were in full possession of the hospital and lifted the restriction on movements allowing the R.A.M.C. to go about their usual duties, which must have been a grim task after the havoc wrought by the murderous troops of the day before, and the thought must have been uppermost in everybody's mind .... the fate of the 400 who had been so senselessly and ruthlessly killed by the Japanese. Apart from the information given by the young oil-covered officer who had escaped, there was no clue as to where the bodies of the dead men were, but it was later found out that they had been thrown into a mass grave.

The Japanese General-officer-Commanding Yamashito appeared and expressed regret at the incident. His explanation for the lack of protection given to the hospital .... its siting between two important military objectives .... the oil tanks in front and the military barracks behind, seemed polite but totally inadequate to explain the unnecessary barbarity of his soldiers. He complimented the Officer Commanding on the way the patients were being cared for and told him to regard himself as a direct representative of the Emperor and that no higher honour could be paid to the hospital. To those survivors who attended the service in the hospital chapel on Monday, 16th February, given by Padre Roberts, must have come heart breaking memories of those who were massacred and the fact of the hospital being honoured by Japan's Emperor must have seemed poor consolation.

War is always a dirty game and things done in battle whose memory must make decent men cringe, but which at the time are necessary in the cause of duty and destruction of the enemy, but the killing and injuries inflicted on the patients and staff of the British Military Hospital in Singapore on Black Friday seem peculiarly horrible insofar as much as the slaughter was unnecessary and the victims, many of them being patients, were so totally vulnerable and defenceless. The courage shown by the people who carried on treating the sick, amongst conditions whose horror doesn't need much imagination to be visualised speaks for itself.

In the two weeks that followed the surrender, the work of the hospital was allowed to go on unhindered and great courtesy was shown by the Japanese. Patients and staff were eventually sent to the internment camp at Changi. The Japanese provided transport, allowing staff to take what medical supplies and equipment they needed.

The lovely building called the British Military Hospital that has been handed over to the Singapore Government looks so tranquil and peaceful that it is hard to believe that for one terrible day its walls and ceilings echoed to the groans and screams of the victims of Japanese atrocity, and its cool floors were slippery with the blood of those who were killed or injured by Japanese bayonets on Black Friday. The final irony is that the cement used for its walls came originally from Japan. 


\section{Acknowledgements}

Acknowledgement is made to Major G. M. G. Atkins, R.A., Captain N. T. Bewick (Retd.), Major T. R. Bond (Retd.), Major H. Gordon, R.A.M.C. (Retd.), J. H. Hammerton, Major C. F. Jackman (Retd.), Irshad Ali Khan, Mrs. I. MacDuff, Colonel D. P. F. Mulvany, R.A.M.C. (Retd.), Captain H. K. Murphy, R.A.M.C., G. L. Peet, A. Roy, Sergeant H. Saye, R.A.M.C. (Retd.), Mr. T. B. Smiley, M.C., F.R.C.S., A. E. Stead, F. H. Sykes, A. S. Taylor, Corporal D. L. Thomas, R.M.P., Major J. Torbit, R.A.M.C., S. G. Upperton (ex Sergeant F.M.S.U.F.), Mr. Tan of the Sing Sing Laundry Co. and The Imperial War Museum, for the information given in the compilation of this document.

\section{BANKERS ORDER}

From (NAME AND RANK IN BLOCK LETTERS)

To the Manager (Bank)

(Branch)

(Address)

Please pay Messrs. Williams \& Glyn's Bank LtD., Kirkland House, Whitehall, S.W.1. for the credit of the funds of the Journal of the Royal Army Medical Corps the sum of

$$
\begin{array}{ll}
* £ 2.50 & \text { Journal and Magazine or } \\
* £ 2.00 & \text { Journal only or } \\
* £ 0.60 & \text { Magazine only. }
\end{array}
$$

being my subscription for the year beginning 1 st 19

and continue such payments yearly on the 1 st till further notice.

Full Postal Address

Signature

Date

To be sent to Manager, Journal of the R.A.M.C., R.A.M. College, Millbank, London, S.W.1 for record and transmission to bank.

*Delete whichever is not applicable. 